\title{
Woolly cupgrass (Eriochloa villosa /Thunb./ Kunth), a recently occured invasive weed in Trans- Tisza Region and a trial for control in maize
}

\author{
${\text { Arnold Szilágyi }{ }^{1} \text { - Zoltán Balogh }}^{2}$ - István Dávid ${ }^{1}$ - László Szabó ${ }^{3}$ - László Radócz ${ }^{1}$ \\ ${ }^{1}$ University of Debrecen, Plant Protection Institute, Debrecen, Hungary \\ ${ }^{2}$ Hungarian Plant Protection Service of the Ministry of Agriculture, Miskolc, Hungary \\ ${ }^{3}$ Hungarian Plant Protection Service of the Ministry of Agriculture, Debrecen, Hungary \\ szilagyi.arnold@agr.unideb.hu
}

\begin{abstract}
Summary:
To the effective control of invasive weeds are essential to prevent establish, if has already happened obstacle to massive accumulation, and promoting the efficient and rapid eradication, if it is possible. The Woolly cupgrass (Eriochloa villosa /Thunb./ Kunth) belongs to weeds which "hard to control" especially in corn. One of the difficulties of effective control is the prolonged emergence causing avoidance of several individuals the contact with pre-emergent herbicides. Another problem arises due to the intensive use of post-emergence herbicide products with short duration of action. To optimalize of timing of treatment is essential for successful control of later emerging weeds. The recently established Woolly cupgrass in Hungary shows resistance or reduced susceptibility to substantial portion of herbicides used in corn. The data collected from small-plot trials demonstrates that application of sulfonylurea or selective monoctyledonous herbicides can be effective against the Woolly cupgrass.
\end{abstract}

Keywords: Wooly cupgrass, Eriochloa villosa, weed control, selective herbicides, maize, corn

\section{Introduction}

The number of weed species affect agricultural production is around 6700. About 200 weed species cause significant problems for crop production worldwide. The accumulation and spread of weeds highly affected by the effectiveness of applied weed control technology in a certain area. Increasing number of new weed species have appeared in Hungary such as Woolly cupgrass (Eriochloa villosa /Thunb./ Kunth). Changes in weed flora elements, appearance of new species can be influenced by:

- changes in farming systems and tillage depth. These can highlight those weed species which are less tolerant for disturbances.

- introduction of non native species by seed, feed, and food trade, transport, stuck in vehicles etc).

- climate change contribution to increase frost-free periods resulting extension of growing season especially for the warm-loving weeds (Szöke, 2001).

The Woolly cupgrass (Eriochloa villosa /Thunb./ Kunth) is widespread in Eastern Europe. Its propsed Hungarian name is 'ázsiai gyapjúfü'. The plant distribution in the temperate zones of Asia, Caucasus, Russia's Far Eastern region, Iran, Japan, China, Taiwan, Korea and Vietnam is common (Tsvelev, 1984). In several states of the United States and Canada was also released. The species has been found in France, Ukraine, Romania and Hungary (Figure 1). The first report about observations was made by János Madarász and Péter Partosfalvi on the 5th (Hungarian) National Weed Surveys in 2007. Partosfalvi et al. (2008) gave an account of occurence of Woolly cupgrass on 25 July 2007, near Gesztely village (North Hungary). Balogh and Novák (2014) shortly reported about spreading of Wooly cupgrass in the northern region and about a herbicide control trial. It is suggested to control in sunflower culture by cycloxydim, a special monocot herbicide which proved proper effectiveness. The Wooly cupgrass plants were also observed in Debrecen (East Hungary) in 2011 on agricultural fields (Figure 2 and Table 1) by László Szabó and István Dávid (unpublished), too.

The proper identification of Eriochloa villosa was confirmed by a grass weed specialist, Prof. Hildemar Scholz (1928-2012).

The Woolly cupgrass belongs to the well adaptable plant species. The Hungarian climate elements provide good conditions for this recently appeared weed. Its favourable conditions are $10-11^{\circ} \mathrm{C}$ average annual temperature, 550-600 mm average annual rainfall, and an average of 5.5-6.5 soil pH (Fărcăşescu et al., 2008). The optimum germination temperature for most of the weeds is between $20-35^{\circ} \mathrm{C}$ (Bello et al., 2000). The germination of Woolly cupgrass starts in mid-April in Hungary. The mass hatching period is followed by a second minor germination peak. Hence, the emergence fully extended, which makes it difficult to control. The ripening of grain yield starts in August and begin to achieve its distribution by animals and human activities. The Woolly cupgrass is classified as a T4 group plant according to the Ujvárosi’ weed plant life system.

Woolly cupgrass gets its name from the hairs covering many parts of the plant. It is a $30-200 \mathrm{~cm}$ annual grass with dark green and densely hairy leaves that have a velvety feel. Only one edge of the leaf blade is typically crinkled, and the flowering branches are also one-sided (Figure 3). The Woolly cupgrass impairs corn, sunflower, soybean areas and stubble-fields. 


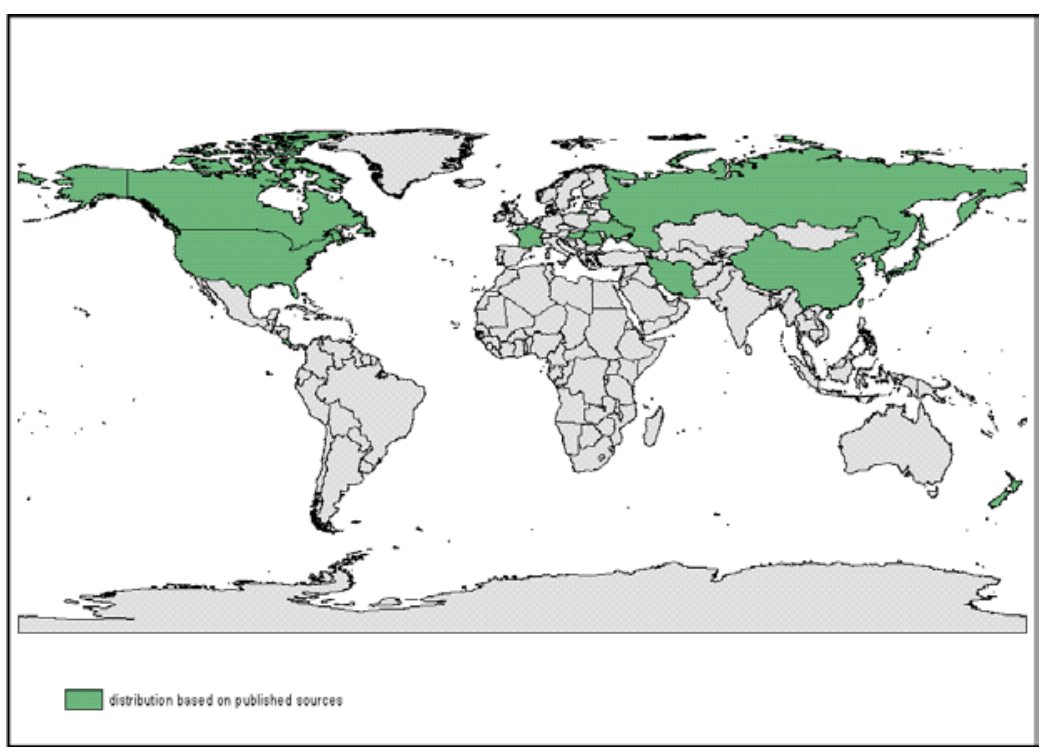

Figure 1: Distribution of Woolly cup grass worldwide (Source: http://www.q-bank.eu/Plants/BioloMICS.aspx?Table=Plants\%20$\% 20$ Species \& Rec $=971 \&$ Fields $=$ All)

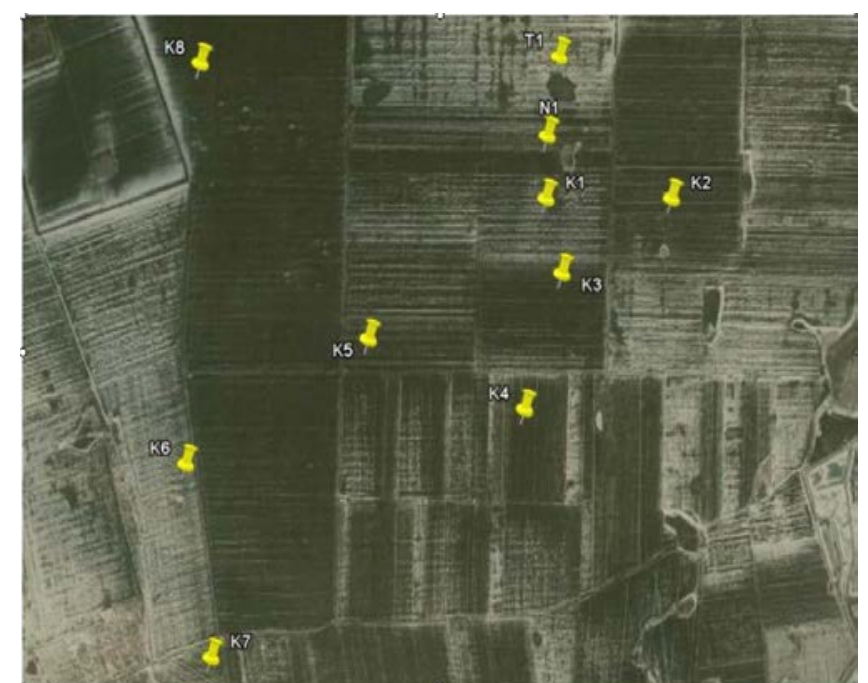

Figure 2: The Woolly cupgrass has been sprading around Debrecen (Source: Indicated points on Google-Earth picture by Somogyi et al., 2011)

K1 - Maize 1, K2 - Maize 2, K3 - Maize 3, K4 - Maize 4, K5 - Maize 5, K5 - Maize 6, K7 - Maize 7, K8 - Maize 8, N1 - Sunflower 1, T1 - Stubble-field 1

Table 1

The dense of Wooly cupgrass on surrounding arable areas of Debrecen, 2011

\begin{tabular}{|c|c|c|c|c|c|c|c|c|}
\hline & \multicolumn{7}{|c|}{ Wooly cupgrass observations on maize fields, Debrecen district, and its proportion in } \\
\hline & $\mathrm{K} 1$ & $\mathrm{~K} 2$ & $\mathrm{~K} 3$ & $\mathrm{~K} 4$ & $\mathrm{~K} 5$ & $\mathrm{~K} 6$ & $\mathrm{~K} 7$ & $\mathrm{~K} 8$ \\
\hline $\begin{array}{c}\text { Infection of Eriochloa villosa on the } \\
\text { maize field }\end{array}$ & 71 & 0 & 2.3 & 0 & 0.2 & 0 & 0.5 & 0 \\
\hline $\begin{array}{c}\text { Infection of Eriochloa villosa on ruderal } \\
\text { areas }\end{array}$ & 71 & 2 & 3 & 4 & 2 & 0.5 & 0.5 & 0.5 \\
\hline
\end{tabular}

(Source: Somogyi et al., 2011) 
$\mathrm{B} /$

A/
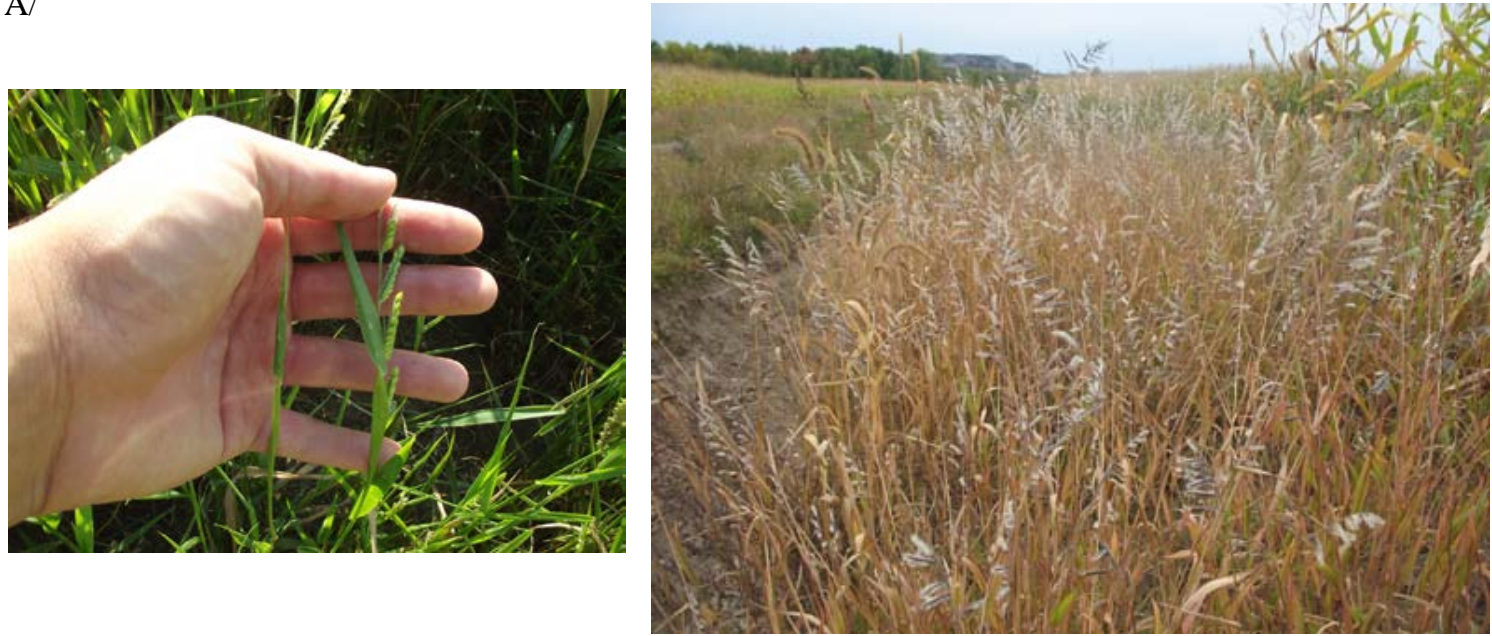

Figure 3: Woolly cupgrass inflorescence branch (A/), infesting the edge of a corn field (B/) (Sources: A: Szilágyi, 2015; B: http://www.inspection.gc.ca/plants/plant-protection/invasive-plants/fact-sheets/woolly-cupgrass/eng/1331822413731/1331822996178)

\section{MATERIALS AND METHODS}

A small-plot herbicide experiment was performed at Gesztely outskirts in 2015. The measurements of the plots: $2 \mathrm{~m}$ wide and $10 \mathrm{~m}$ long. The plots of nine post-emergent herbicide treatments and untreatment ones were designed in randomized block in 4 repetitions. The maize field was totally infested by Wooly cupgrass. The coordinates of trial the follows in UTM system:
1. 48 $12^{\prime} 80.63^{\prime \prime}$ 20'99'34.63"
2. $48^{\circ} 12^{\prime} 80.92^{\prime \prime}$ $20^{\circ} 99^{\prime} 36.78^{\prime \prime}$
3. $48^{\circ} 12^{\prime} 65.81^{\prime \prime}$ 20'99'38.92"
4. $48^{\circ} 12^{\prime} 65.95^{\prime \prime}$ 209'40.86” (Figure 4).

The maize hybrid was the Focus Ultra (cycloxydim) resistant, calls Duo System. The spraying of plots was made on 08 June 2015 by a special plot sprayer.

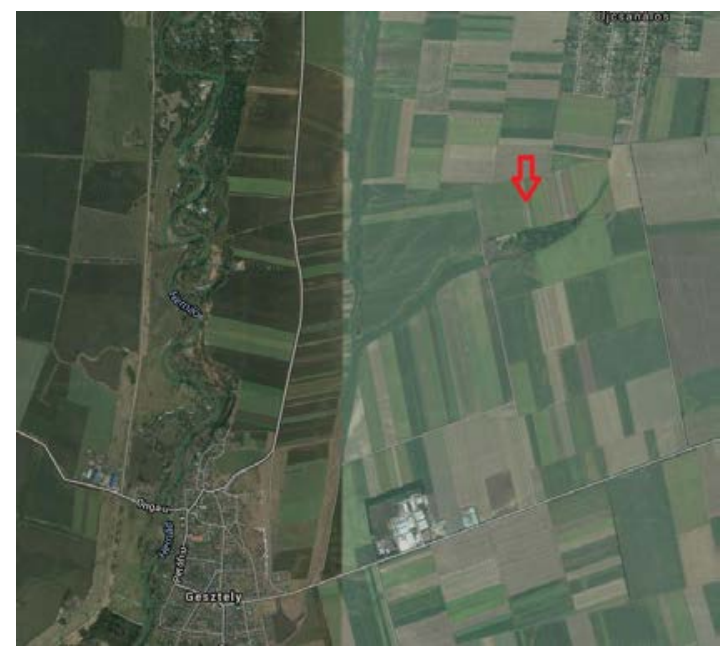

Figure 4: Place of small plot trial next to Gesztely, 2015 (Source: Google Earth) 


\section{RESULTS}

The effectiveness of post-emergent herbicide treatments is shown in the Table 2. The most of herbicides which generally used in maize production reached weak or very poor rating. So those areas, which heavy infested by Wolly cupgrass, there are very important to apply a wide range of weed control. Because of weak effectiveness of post-emergent herbicides, it sholud be reasonable to find effective pre-emergence herbicides, which could suppress the emergence of the first wave of weeds including Wooly cupgrass. The post-emergent herbicides can push back the late germinating Wolly cupgrass with weak effectiveness only.

Table 2

Effectiveness of herbicide treatment in maize (Gesztely, 2015)

\begin{tabular}{|c|c|c|c|c|}
\hline \multirow{2}{*}{$\begin{array}{l}\text { Treatments } \\
\text { (Number) }\end{array}$} & \multirow[t]{2}{*}{ Active substances } & \multirow{2}{*}{$\begin{array}{c}\text { Dose } \\
\text { (kg/ha, l/ha, \%) }\end{array}$} & \multicolumn{2}{|c|}{ Effectiveness } \\
\hline & & & $\%$ & Textually \\
\hline 1 & $\begin{array}{l}\text { nicosulfuron } \\
\text { dicamba }\end{array}$ & $\begin{array}{l}1.5 \\
0.6 \\
\end{array}$ & 71 & weak \\
\hline 2 & $\begin{array}{l}\text { nicosulfuron } \\
\text { dicamba } \\
\text { ethoxylated isodecyl alcohol }\end{array}$ & $\begin{array}{l}1.5 \\
0.6 \\
0.3 \\
\end{array}$ & 83 & weak \\
\hline 3 & $\begin{array}{l}\text { nicosulfuron + rimsulfuron } \\
\text { dicamba } \\
\text { ethoxylated isodecyl alcohol }\end{array}$ & $\begin{array}{c}0.09 \\
0.6 \\
0.3\end{array}$ & 65 & very weak \\
\hline 4 & $\begin{array}{l}\text { mesotrione }+ \text { nicosulfuron }+ \\
\text { prosulfuron } \\
\text { dicamba } \\
\text { modified trisiloxane }+ \text { polyester }\end{array}$ & $\begin{array}{c}2 \\
0.017 \\
0.6 \\
0.2\end{array}$ & 85 & weak \\
\hline 5 & $\begin{array}{l}\text { nicosulfuron } \\
\text { dicamba } \\
\text { plant oil fatty acid methyl ester (FAME) } \\
+\quad \text { etoxylated alcohols }+ \text { alkyl } \\
\text { polyglykoside citrate }\end{array}$ & $\begin{array}{c}0.25 \\
0.6 \\
0.6\end{array}$ & 67 & very weak \\
\hline 6 & $\begin{array}{l}\text { foramsulfuron + thiencarbazone-methyl } \\
+ \text { ciprosulfamid } \\
\text { dicamba }\end{array}$ & $\begin{array}{l}2.0 \\
0.6 \\
\end{array}$ & 50 & very weak \\
\hline 7 & $\begin{array}{l}\text { topramezon } \\
\text { dicamba } \\
\text { methyil oleate+ methyl palmitate }\end{array}$ & $\begin{array}{c}0.15 \\
0.6 \\
1.2\end{array}$ & 56 & very weak \\
\hline 8 & $\begin{array}{l}\text { tembotrion }+ \text { thiencarbazone-methyl }+ \\
\text { izoxadifen-ethyl } \\
\text { dicamba } \\
\text { demetilated rape oil }\end{array}$ & $\begin{array}{l}0.44 \\
0.6 \\
2.0\end{array}$ & 62 & very weak \\
\hline 9 & $\begin{array}{l}\text { sulcotrione } \\
\text { dicamba }\end{array}$ & $\begin{array}{c}2 \\
0.6\end{array}$ & 45 & very weak \\
\hline
\end{tabular}

\section{CONCLUSIONS}

The Wooly cupgrass is a new invasive weed species in Hungary, which was detected at the first time in Gesztely (North-Hungary) in 2007, then it occurred the outskirts of Debrecen (East-Hungary) in 2011. The main objective of the herbicide trial was to find an effective herbicide against Woolly cupgrass in maize culture. On the base of foreign literature the use of sulphonylureas, including nicosulfuron proved to be weak but acceptable effectiveness (65-85\%). The mesotrione + nicosulfuron + prosulfuron + dicamba + trisiloxane added with modified polyester herbicide mixture achieved the best results with a $85 \%$ efficiency. The most effective defense preemergence and postemergence according to a combination only defense, because of the delayed emergence. By avoidance of monocultural maize production practice and keeping a four-five-year crop rotation successfully can be avoid the Woolly cupgrass accumulation in soils. In dicotyledonous cultures the application of cycloxydim active substance can also be effective that inhibits the acetylcoenzyme A carboxylase (ACCase) in chloroplasts of sensitive weeds.

The ruderal areas play role in the maintenance of Woolly cupgrass producing many seeds to survive and spread. 


\section{REFERENCES}

Balogh, Z. and Novák, R. (2014): Adatok az ázsiai gyapjúfü (Eriochloa villosa) Borsod-Abaúj-Zemplén Megyei terjedéséhez és az ellene való védekezés lehetőségeihez. NTN 2014, Abstracts 79.

Bello, I.A. - Hatterman-Valenthi, H. - Owen, M.D.K.( 2000): Factors affecting germination and seed production of Eriochloa villosa. Weed Science 48: 749-754.

Ciocarlan, V. - Sike, M. (2006): Eriochloa villosa (Thunb.) Kunth (Poaceae) in the Romanian flora. Journal of Plant Development 13: 105107.

Fărcăşescu, A.M. - Arsene, G.G. - Neacsu, A.G. (2008): Eriochloa villosa (Thunb.) Khunt - a new invasive weed in Romania. Journal of Plant Diseases and Protection, Special Issue 21: 333-334.

Hinz, J.R.R. - Owen, M.D.K. - Barrett, M. (1997): Nicosulfuron, primisulfuron, and bentazon hydroxylation by corn (Zea mays), woolly cupgrass (Eriochloa villosa), and shattercane (Sorghum bicolor) cytochrome P-450. Weed Science 45: 474-480.

Mickelson, J.A. - Midhtun-Hensen, A. - Harvey, R.G. (2004): Fate and persistence of woolly cupgrass (Eriochloa villosa) seed banks. Weed Science 52: 346-351.

Partosfalvi, P. - Madarász, J. - Dancza, I. (2008): Occurrence of Eriochloa villosa (Thunb.) Kunth in Hungary. Növényvédelem $44(6)$ : 304.

Somogyi N. - Szabó L. - Dávid I. (2011): Az ázsiai gyapjúfü (Eriochloa villosa /Thunb./ Kunth) megjelenése Hajdú-Bihar megyében. Agrártudományi Közlemények 2011/43: 119-123.

Szőke, L. (2001): A melegigényes gyomfajok gyors terjedése és a klímaváltozás összefüggése. Növényvédelem 37(1): 10-12.

Tsvelev, N.N. (1984): Grasses of the Soviet Union. Vol -II. transl. Balkema, A.A., Rotterdam. (Russian translations series No. 8) pp. 1196. 